Anay's Will to Learn 
THIS PAGE INTENTIONALLY LEFT BLANK 
BY ELAINE M. HAMPTON WITH

ANAY PALOMEQUE DE CARRILLO

\section{Anay's Will to Learn}

A WOMAN'S EDUCATION IN THE

SHADOW OF THE MAQUILADORAS

University of Texas Press $\mathbf{v}$ AUstin 
Copyright (C) 2013 by the University of Texas Press

All rights reserved

Printed in the United States of America

First edition, 2013

Requests for permission to reproduce material from this work should be sent to:

Permissions

University of Texas Press

P.O. Box 7819

Austin, TX 78713-7819

http://utpress.utexas.edu/about/book-permissions

(2) The paper used in this book meets the minimum requirements of ANSI/NISO Z39.48-1992 (R1997) (Permanence of Paper).

LIBRARY OF CONGRESS CATALOGING-IN-PUBLICATION DATA

Hampton, Elaine M., 1948-

Anay's will to learn : a woman's education in the shadow of the Maquiladoras / By Elaine M. Hampton with Anay Palomeque de Carrillo.

$\mathrm{p} \quad \mathrm{cm}$

Includes bibliographical references and index.

ISBN 978-0-292-74426-4 (cloth: alk. paper)

1. Women-Education-Mexico. 2. Women-Mexico-Social conditions. 3. Offshore assembly industry-Mexico. I. Carrillo, Anay Palomeque de. II. Title.

LC1772.H36 2013

$305.420972-\mathrm{dc2} 3$

2012032675

doi:10.756o/744264 
Dedicated to Eva, Juliet, Elaincita, Kiké, Callye, John, Sophie, Addie, and Tate with the hope for a future full of cross-cultural communications for mutual learning and mutual benefit. 
THIS PAGE INTENTIONALLY LEFT BLANK 